\title{
PENGARUH INDEPENDENSI, KOMPETENSI, DAN PARTISIPASI DEWAN KOMISARIS TERHADAP KINERJA KEUANGAN PERUSAHAAN
}

\author{
Feilicia Octosiva, Meilisa Theresia, Athalia Ariati Hidayat \\ Sekolah Bisnis dan Ekonomi - Universitas Prasetiya Mulya \\ BSD City Kavling Edutown I.1 , Jl. BSD Raya Utama, BSD City, Tange rang 15339
}

Keywords:

Competence, corporate financial performance, Independency, participation

\section{Kata kunci:}

Kompetensi, kinerja keuangan perusahaan, independensi, partisipasi

Corres ponding Author: feiliciaoctosiva@gmail.com

\begin{abstract}
According to the Asian Development Bank report, responsibility of the board is one of the principles that has not been implemented properly in Indonesia. There are several things that can represent the responsibilities of the board such as independency, competence, and participation. The aim to this study is to analyze the effect of the independency proxied by the proportion of independent commissioners, the competence proxied by the board's working experience in the major industry of the company, and the participation proxied by the average percentage attendance of the board in the meeting to corporate financial performance represented with ROA. The sample used in this study is in the period of 2011 2015 with a total of 1229 firm-years. The hypothesis testing in this research uses panel data regression analysis. The result shows that independency of the board has no effect to corporate financial performance, while the competence of the board has a positive effect to corporate financial performance and participation of the board shows a negative effect to corporate financial performance.
\end{abstract}

\section{SARI PATI}

Menurut laporan dari Asian Development Bank, salah satu prinsip tata kelola perusahaan yang belum diimplementasikan dengan baik di Indonesia adalah tanggung jawab dewan komisaris. Terdapat beberapa hal yang dapat menggambarkan tanggung jawab dewan komisaris antara lain independensi, kompetensi, dan partisipasi. Penelitian ini bertujuan untuk menganalisis pengaruh independensi yang diproksikan dengan proporsi komisaris independen, kompetensi yang diproksikan dengan proporsi dewan komisaris yang berasal dari industri utama perusahaan beroperasi, dan partisipasi yang diproksikan dengan rata-rata persentase kehadiran dewan komisaris dalam rapat terhadap kinerja keuangan perusahaan yang diproksikan dengan ROA. Sampel penelitian berjumlah 1229 perusahaan-tahun yang meliputi periode 2011-2015. Pengujian dilakukan dengan regresi data panel. Hasil pengujian menunjukkan bahwa independensi dewan komisaris tidak berpengaruh terhadap kinerja keuangan perusahaan, sedangkan kompetensi dewan komisaris berpengaruh positif dan partisipasi dewan komisaris berpengaruh negatif terhadap kinerja keuangan perusahaan. 


\section{Pendahuluan}

Undang-Undang No. 40 Tahun 2007 tentang Perseroan Terbatas dinyatakan bahwa organ perusahaan terdiri dari Rapat Umum Pemegang Saham, Direksi, dan Dewan Komisaris. Dewan komisaris memiliki peran penting karena dewan komisaris bertugas untuk mengawasi kebijakan perusahaan, jalannya kepengurusan pada umumnya, dan memberi nasihat kepada direksi (Widjaja, 2008).

Terdapat tiga hal yang dapat dilihat terkait dewan komisaris, antara la in adalah independensi, kompetensi, dan partisipasi. Pertama, independensi yang ditunjukkan melalui komisaris independen. Komisaris independen diperlukan untuk meningkatkan independensi dewan komisaris terhadap kepentingan pemegang saham (mayoritas) dan diharapkan benar-benar menempatkan kepentingan perusahaan di atas yang lainnya (Muntoro, 2006). Selain itu, komisaris independen adalah orang yang dipercaya oleh pemegang saham dan diharapkan akan membantu untuk mengurangi masalah keagenan (Fuzi, Halim, dan Julizaerma, 2016). Hal ini juga berhubungan dengan teori keagenan bahwa komisaris independen diharapkan dapat menjalankan fungsinya dengan sebaik-baiknya sebagai agen yang melakukan pengawasan atas kinerja direksi dan manajemen. Tidak hanya itu saja, hal ini dapat dikaitkan juga dengan teori stewardship bahwa komisaris independen diharapkan dapat patuh dan termotivasi untuk mencapai tujuan perusahaan. Kedua adalah kompetensi, diharapkan dewan komisaris memiliki kemampuan yang mencakup keahlian dalam industri yang akan dijalankan sehingga dapat memenuhi kebutuhan organisasi (Muntoro, 2006). Terakhir adalah partisipasi yang difokuskan pada kehadiran dalam rapat. Hal ini menjadi penting karena rapat merupakan wadah yang mempertemukan dewan komisaris dan mereka dapat saling berdiskusi dan mengambil keputusankeputusan penting bagi perusahaan. Selain itu, kehadiran dalam rapat menjadi bukti akan minat dan tanggung jawab dewan komisaris terhadap perusahaan.

Berdasarkan penjabaran di atas, untuk mengetahui apakah implementasi tata kelola sudah dijalankan dengan baik atau belum dapat dilihat melalui kinerja perusahaan dengan menggunakan laporan keuangan perusahaan sebagai acuan bagi investor maupun pemangku kepentingan (stakeholders) lainnya. Analisis rasio yang ada pada laporan keuangan perusahaan merupakan salah 
satu cara untuk mengetahui kinerja perusahaan secara keseluruhan maupun secara mendetail dari waktu ke waktu (Kuswadi, 2006).

Amyulianthy (2012), Widyati (2013), serta Hidayat dan Utama (2015) menemukan bahwa independensi dewan komisaris berpengaruh positif terhadap kinerja keuangan perusahaan, namun di sisi lain ada yang menemukan bahwa hasilnya tidak berpengaruh seperti penelitian dari Wulandari (2006) dan Nathania (2014). Untuk variabel kompetensi dewan komisaris, penelitian ini ingin melihat sisi lain dari kompetensi dewan komisaris karena beberapa penelitian sebelumnya membahas kompetensi dari sisi latar belakang pendidikan dan latar belakang akuntansi ataupun keuangan. Sedangkan penelitian ini ingin menguji kompetensi berdasarkan pengalaman bekerja dari industri yang sama dari dewan komisaris tersebut. Variabel yang terakhir adalah partisipasi dewan komisaris.

Jika sebelumnya beberapa penelitian membahas mengenai frekuensi rapat, namun pene litian ini ingin membahas berdasarkan rata-rata persentase kehadiran dewan komisaris dalam rapat. Berdasarkan penjabaran di atas, penelitian ini dilakukan untuk menganalis is dampak independensi, kompetensi, dan partisipasi terhadap kinerja keuangan perusahaan. Berdasarkan beberapa hal yang diuraikan di atas, maka tujuan yang hendak dicapai pada penelitian ini adalah untuk menganalisis pengaruh independensi, kompetensi, dan partisipasi dewan komisaris terhadap kinerja keuangan perusahaan.

\section{Landasan Teori dan Pengembangan Hipotesis}

\section{Konsep Tata Kelola Perusahaan (Good Corporate Governance)}

Tata kelola perusahaan adalah sistem, proses, dan seperangkat peraturan yang mengatur hubungan antara berbagai pemangku kepentingan (Haris, 2005). Dalam arti sempit, tata kelola perusahaan mengatur hubungan antara pemegang saham, dewan komisaris, dan direksi demi tercapainya tujuan organisasi (Haris, 2005). Hal ini juga disampaikan oleh Monks (2003, dalam Kaihatu, 2006) yang mendefinisikan GCG sebagai sistem yang mengatur dan mengendalikan perusahaan yang menciptakan nilai tambah bagi semua pemangku kepentingan. Konsep ini menekankan pada pentingnya hak pemegang saham dalam memperoleh informasi yang benar dan tepat waktu. Menurut Komite Nasional Kebijakan Governance (KNKG, 2006), terdapat lima prinsip 
tata kelola perusahaan yang baik, yaitu transparansi, akuntabilitas, responsibilitas, independensi, dan kesetaraan.

Lebih lanjut, berdasarkan prinsip yang tercantum dalam Organisation for Economic Cooperation and Development (OECD, 2015), suatu perusahaan dapat dikatakan memiliki tata kelola perusahaan yang baik apabila mengimplementasikan beberapa prinsip sebagai berikut:

1. Ensuring the basis for an effective corporate governance framework:

2. The rights and equitable treatment of shareholders and key ownership functions:

3. Institutional investors, stock markets, and other intermediaries:

4. The role of stakeholders in corporate governance:

5. Disclosure and transparency:

6. The responsibilities of the board:

Penelitian ini hanya difokuskan pada prinsip keenam, yaitu pertanggungjawaban dewan (the responsibilities of the board) yang berkaitan dengan independensi, kompetensi, dan partisipasi dewan. Dengan memenuhi prinsip-prinsip tersebut, suatu perusahaan dapat dikatakan telah mengimplementasikan tata kelola perusahaan yang baik. Organ perusahaan yang terdiri dari Rapat Umum Pemegang Saham (RUPS), dewan komisaris dan direksi, mempunyai peran penting dalam pelaksanaan GCG secara efektif. Berdasarkan Undang-Undang No. 40 Tahun 2007 tentang Perseroan Terbatas, Indonesia menganut sistem two-tier board yang menyebabkan fungsi dan tanggung jawab dari dewan direksi dan dewan komisaris berbeda. Dewan direksi adalah organ perusahaan yang berwenang dan bertanggung jawab penuh atas pengurusan perusahaan untuk kepentingan perusahaan sesuai dengan maksud dan tujuan perusahaan serta mewakili perusahaan baik di dalam maupun di luar pengadilan sesuai dengan ketentuan anggaran dasar.

Di sisi lain, dewan komisaris didefinisikan sebagai organ perusahaan yang bertugas melakukan pengawasan secara umum dan/atau khusus sesuai dengan anggaran dasar serta memberi nasihat kepada direksi. Dengan kata lain, dewan direksi memiliki peran dalam melakukan manajemen operasional perusahaan dan dewan komisaris memerankan fungsi pengawasan di perusahaan (UU No. 40 Tahun 2007 tentang Perseroan Terbatas). Dalam pelaksanaan GCG, dewan komisaris memegang 
peranan yang sangat penting dalam perusahaan (FCGI, 2001). Menurut Egon Zehnder International (2000, dalam FCGI, 2001), dewan komisaris merupakan inti dari tata kelola perusahaan yang baik yang memiliki tugas untuk menjamin pelaksanaan strategi perusahaan, melakukan pengawasan terhadap manajemen dalam mengelola perusahaan, serta mewajibkan terlaksananya akuntabilitas.

\section{Pengembangan Hipotesis}

\section{Pengaruh Independensi Dewan Komisaris Terhadap Kinerja Keuangan Perusahaan}

Komisaris independen dapat membuat dewan komisaris bersifat objektif saat mengambil keputusan dalam mengeva luasi kinerja manajemen perusahaan (Otoritas Jasa Keuangan, 2014). Selain itu, komisaris independen dapat mengurangi terjadinya masalah keagenan.

Penelitian O’Connell dan Cramer di Irlandia (2010), Liu, Miletkov, Wei, dan Yang di China (2015), Dharmadasa, Gamage, dan Herath di Sri Lanka (2014), Amyulianthy (2012), Widyati (2013), serta Hidayat dan Utama (2015) di Indonesia menunjukkan adanya hubungan positif dan signifikan antara independensi dewan komisaris dengan kinerja keuangan perusahaan. Dijelaskan lebih lanjut hal ini dapat terjadi karena komisaris independen dianggap sebagai pihak independen yang tidak memiliki kepentingan dalam perusahaan, sehingga dapat melindungi kepentingan saham minoritas. Selain itu, komisaris independen dapat mengurangi masalah keagenan yang terjadi karena keinginan mayoritas pemegang saham untuk mengambil alih pemegang saham minoritas dan kepercayaan dari investor serta tata kelola perusahaan yang baik di perusahaan akan menciptakan profitabilitas yang baik bagi perusahaan. Penelitian oleh Barnhart dan Rosenstein (1998) dalam Nasser (2008) juga menyatakan bahwa hubungan antara independensi dewan komisaris dan kinerja keuangan perusahaan adalah positif karena semakin tinggi proporsi komisaris independen, maka semakin tinggi pula tingkat independensi dan efektifitas dewan perusahaan sehingga dapat meningkatkan kinerja keuangan perusahaan.

Hal la in ditemukan oleh Erickson, Park, Reising, dan Shin (2005) di Kanada serta Hsu (2010) di Amerika Serikat, bahwa independensi dewan komisaris berpengaruh negatif signifikan terhadap kinerja keuangan perusahaan. Menurut Agrawal dan Knoeber (1996) di Amerika Serikat, pemilihan komisaris independen ini dapat dikaitkan dengan motivasi perusahaan yang mengarah ke lingkup 
politik. Duchin, Matsusaka, dan Ozbas (2010) di Amerika Serikat juga menyatakan bahwa pengangkatan komisaris independen dapat berdasarkan keinginan dari pemegang saham dengan pertimbangan bahwa orang yang dipilihnya tersebut memiliki hubungan yang baik dengannya. Selain itu, Duchin et al. menemukan bahwa adanya komisaris independen dalam perusahaan hanya untuk pemenuhan peraturan dan tata kelola perusahaan saja tanpa benar-benar menjalankan fungsi komisaris independen tersebut.

Namun, di Malaysia (Johl, Kaur, dan Cooper, 2015) menemukan bahwa independensi dewan komisaris tidak terbukti dapat memengaruhi kinerja keuangan perusahaan. Hal tersebut serupa dengan temuan di Yunani (Drakos dan Bekiris, 2010), Kenya (Ongore, K'Obonyo, Ogutu, dan Bosire; 2015), dan Indonesia (Wulandari, 2006 dan Nathania, 2014). Tidak adanya pengaruh antara independensi dewan komisaris dan kinerja keuangan perusahaan dapat terjadi antara lain karena masih banyak komisaris independen yang diangkat bukan karena alasan kemampuan, pengalaman, dan pengetahuan yang dimiliki melainkan karena kepentingan tertentu terhadap perusahaan dan pemilihannya secara subjektif. Komisaris independen juga merupakan orang yang bekerja paruh waktu dan memiliki komitmen pekerjaan di tempat lain sehingga tidak sepenuhnya mengetahui apa yang terjadi di dalam perusahaan sehari-hari dan tidak memiliki informasi yang cukup untuk ikut andil dalam perusahaan.

Akan tetapi, bagaimanapun juga independensi dewan komisaris tetap diperlukan dan diwajibkan di dalam perusahaan yang bilamana fungsi-fungsinya dijalankan dengan baik, akan berpengaruh positif bagi perusahaan. Selain itu, jika independensi dewan komisaris semakin tinggi, diharapkan tingkat pengawasan juga semakin tinggi dan akan semakin objektif, sehingga kemungkinan direksi melakukan kecurangan semakin kecil yang akan berdampak pada meningkatnya kinerja keuangan perusahaan.

Terkait independensi komisaris independen, roadmap tata kelola perusahaan Indonesia dan ASEAN Corporate Governance Scorecard menyatakan bahwa independensi tergantung kepada beberapa kriteria antara lain lama masa jabatan sebagai komisaris independen dalam perusahaan tersebut dan jumlah jabatan sebagai dewan di perusahaan lain. Lama masa jabatan seorang komisaris independen dapat memengaruhi tingkat independensi karena jika semakin lama menjabat di 
perusahaan tersebut, komisaris independen sudah akrab dan kenal baik dengan para dewan dan manajemen. Selain itu, diperlukannya regenerasi komisaris independen agar komposisi orang yang ada di perusahaan tidak didominasi oleh orang-orang tertentu saja dan organisasi perusahaan menjadi lebih segar dengan adanya orang-orang baru.

Menurut ASEAN Corporate Governance Scorecard, batas masa jabatan dari seorang komisaris independen adalah sembilan tahun, sehingga jika lebih dari sembilan tahun dapat dikatakan bahwa komisaris independen tersebut sudah tidak independen. Kriteria ini didukung penelitian sebelumnya oleh Hidayat dan Utama (2015). Hal selanjutnya yang memengaruhi independensi adalah jumlah jabatan sebagai dewan yang dijabat oleh komisaris independen di perusahaan lain. Jumlah jabatan ini berpengaruh karena semakin banyak menjabat sebagai dewan, maka fokus dan komitmen dari komisaris independen tersebut akan terpecah sehingga performa komisaris independen akan terganggu. Berdasarkan ASEAN Corporate Governance Scorecard, batas jumlah jabatan dewan yang dijabat oleh komisaris independen adalah lima jabatan, jika lebih dari lima jabatan maka komisaris independen sudah tidak termasuk kategori independen. Dengan adanya kedua kriteria ini, diharapkan independensi dewan komisaris dapat meningkat, sehingga akan memengaruhi kinerja keuangan perusahaan. Berdasarkan uraian di atas, hipotesis dalam penelitian ini adalah:

$\mathbf{H}_{1}$ : Semakin tinggi independensi dewan komisaris, maka semakin tinggi kinerja keuangan perusahaan.

\section{Pengaruh Kompetensi Dewan Komisaris Terhadap Kinerja Keuangan Perusahaan}

Kompetensi dewan komisaris mempunyai peran penting dalam menentukan kesuksesan perusahaan (Otoritas Jasa Keuangan, 2014). Untuk mendapatkan dewan komisaris yang berkompeten, perusahaan harus memiliki informasi yang cukup mengenai dewan komisaris tersebut, apakah dewan komisaris tersebut memiliki kualifikasi tertentu dan pengalaman yang cukup untuk menempati posisi dewan komisaris tersebut.

Berdasarkan kriteria dari ASEAN Corporate Governance Scorecard, kompetensi dewan komisaris didasarkan pada pengalaman industri dewan komisaris. Dalam hal ini akan dilihat apakah sebelumnya dewan komisaris memiliki pengalaman pada industri yang akan dijalankan. Dari 
beberapa penelitian yang peneliti temukan, belum banyak yang mendefinisikan kompetensi dengan pengalaman industri dari dewan komisaris tersebut. Penelitian lain mendefinisikan kompetensi dengan latar belakang pendidikan serta latar belakang akuntansi dan keuangan, sehingga pengalaman industri ini menjadi hal yang menarik untuk diteliti lebih lanjut.

Kor (2003) di Amerika Serikat menemukan bahwa pengalaman industri dari dewan komisaris meningkatkan kinerja perusahaan. Dewan komisaris yang telah memiliki pengalaman dalam industri terkait akan lebih mudah mengerti dinamika dari industri tersebut. Selain itu, pengetahuan akan teknologi dan kondisi pasar dari industri terkait akan membuat dewan komisaris lebih mudah melihat peluang dan tren terbaru yang ada dalam perusahaan tersebut. Dengan adanya penga laman industri ini, dewan komisaris diharapkan akan memberikan nilai tambah positif untuk kinerja perusahaan karena telah mengetahui seluk beluk dari industri yang sedang dijalankan serta dapat membantu perusahaan menghindari membuat keputusan-keputusan yang tidak baik yang akan memengaruhi berjalannya perusahaan.

Dalam penelitiannya yang lebih lanjut, Kor dan Misangyi (2008) menemukan bahwa ternyata hal ini lebih berpengaruh bagi perusahaan startup dibandingkan perusahaan yang sudah lama berdiri. Hal ini dikarenakan saran dan nasihat dari dewan komisaris yang pakar dibidangnya lebih dibutuhkan untuk awal berdirinya perusahaan karena fase awal dalam bisnis merupakan fase yang cukup krusial dalam hal penelitian dan pengembangan untuk menemukan pasar yang tepat. Tetapi tidak menutup kemungkinan bahwa pengalaman industri ini akan memberikan dampak yang positif untuk seluruh perusahaan. Hal ini disebabkan setiap industri memiliki karakteristik yang berbeda-beda, sehingga alangkah lebih baik jika dewan komisaris memiliki pengalaman industri yang relevan dengan perusahaan yang akan dijalani saat ini. Dengan banyaknya dewan komisaris yang memiliki pengalaman industri, maka semakin banyak pengetahuan akan industri tersebut yang akhirnya akan mendukung perusahaan untuk semakin bertumbuh. Berdasarkan uraian di atas, hipotesis kedua pada penelitian ini adalah:

$\mathbf{H}_{2}$ : Semakin tinggi kompetensi dewan komisaris, maka semakin tinggi kinerja keuangan perusahaan. 
Partisipasi dewan komisaris dapat ditunjukkan melalui keaktifan dan keinginan untuk turut serta dalam hal yang diselenggarakan oleh perusahaan, contohnya adalah kehadiran dalam rapat. Dalam hal ini, partisipasi dalam rapat menjadi bagian penting karena para dewan komisaris dapat memberikan pendapat-pendapat dan keputusan penting untuk jalannya perusahaan, sehingga jika dewan komisaris turut aktif dalam rapat ini, seharusnya akan memberikan keputusan yang baik yang akhirnya dapat meningkatkan kinerja perusahaan. Kehadiran dalam rapat ini juga menjadi pembuktian bagi dewan komisaris akan komitmen dalam menjalankan tanggung jawab mereka. Selain itu, rapat yang terencana dengan baik akan mendukung terwujudnya hasil yang optimal dari rapat, berupa pengambilan keputusan yang efisien dan efektif (Otoritas Jasa Keuangan, 2014). Kehadiran dalam rapat ini juga sesuai dengan kriteria yang ada di ASEAN Corporate Governance Scorecard. Namun, beberapa penelitian terutama di Indonesia masih banyak yang belum meneliti kehadiran dalam rapat namun hanya frekuensi rapatnya saja, sehingga hal ini menjadi hal yang menarik untuk diteliti.

Lin, Yeh, dan Yang (2014) di Taiwan, Bhatt dan Bhattacharya (2015) di India, serta Kim (2011) di Korea menemukan bahwa semakin tinggi kehadiran dewan komisaris dalam rapat akan meningkatkan kinerja perusahaan. Kehadiran dalam rapat merupakan salah satu cara bagi dewan komisaris untuk dapat memberikan pengaruh dalam perusahaan melalui keputusan-keputusan dan rencana-rencana yang dibuat dalam rapat tersebut. Selain itu, kehadiran dalam rapat ini dapat memperlihatkan keaktifan dari dewan komisaris, serta minat dan tanggung jawab dewan komisaris terhadap perusahaan.

Namun, hubungan ini dapat menjadi negatif menurut penelitian dari Chou, Chung, dan Yin (2013) di Taiwan jika yang menghadiri rapat bukanlah dewan komisaris itu sendiri namun perwakilannya. Akan tetapi, jika yang menghadiri rapatnya adalah dewan komisaris itu sendiri tanpa mendelegasikan ke perwakilannya, hubungannya menjadi positif. Kehadiran dalam rapat juga dapat menjadi salah satu pengukur kinerja dewan komisaris yang dapat dilihat melalui keaktifan untuk mau datang serta keaktifan saat berada di dalam rapat. Sehingga semakin tinggi kehadiran dewan komisaris dalam rapat, maka menunjukkan keterlibatan dan komitmen yang semakin tinggi pada 


\section{saki}

Studi Akuntansi \& Keuangan Indonesia

perusahaan yang akan mengarahkan pada tercapainya tujuan perusahaan. Berdasarkan uraian di atas, hipotesis ketiga pada penelitian ini adalah:

$\mathbf{H}_{3}$ : Semakin tinggi partisipasi dewan komisaris, maka semak in tinggi kinerja keuangan perusahaan.

\section{Kerangka Penelitian}

\section{Gambar 2.1 Kerangka Penelitian}

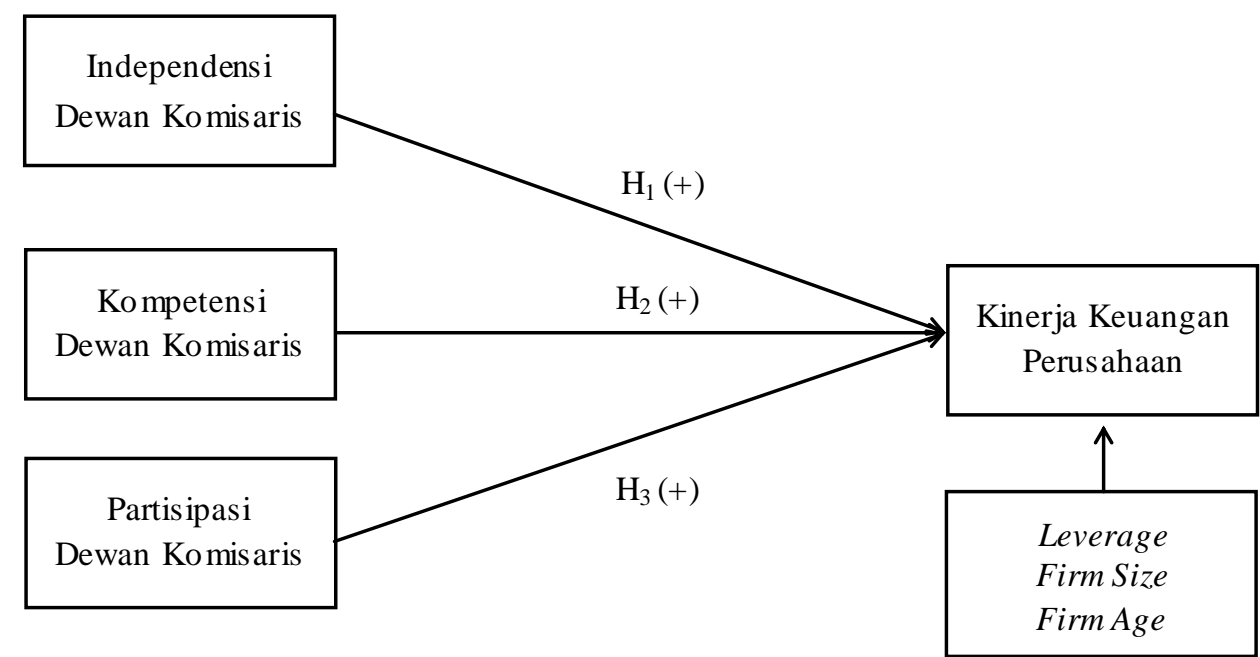

\section{Metode Penelitian}

\section{Data dan Pemilihan Sampel Penelitian}

Data yang digunakan dalam penelitian ini adalah data sekunder. Data ini didapatkan dari Capital IQ dan laporan tahunan yang diunduh dari website Bursa Efek Indonesia (BEI). Sampel penelitian yang dipilih adalah semua perusahaan yang memiliki data independensi, kompetensi, dan partisipasi dewan komisaris dari tahun 2011-2015 serta informasi mengenai kinerja keuangan perusahaan yang diproksikan dengan ROA. Berdasarkan kriteria tersebut, teknik yang digunakan dalam pengambilan sampel adalah purposive sampling. Periode 2011-2015 yang dipilih dalam penelitian ini karena merupakan tahun setelah krisis dan periode lima tahun terakhir dan terbaru yang lebih memungkinkan untuk didapatkan laporan keuangannya. Total data yang digunakan dalam penelitian ini adalah 1229 data.

\section{Operasionalisasi Variabel}

Operasionalisasi variabel ditampilkan pada Tabel 3.1. 
Tabel 3.1 Ope rasionalisasi Variabel

\begin{tabular}{|c|c|c|c|c|}
\hline $\begin{array}{c}\text { Jenis } \\
\text { Variabel/Indikat } \\
\text { or } \\
\end{array}$ & Proksi & Formula & $\begin{array}{l}\text { Jenis } \\
\text { Data }\end{array}$ & Sumber \\
\hline \multicolumn{5}{|l|}{ Variabel Dependen } \\
\hline $\begin{array}{c}\text { Kinerja Keuangan } \\
\text { Perusahaan }\end{array}$ & $\begin{array}{l}\text { Return on Assets } \\
\text { (ROA) }\end{array}$ & $\begin{array}{c}\mathrm{ROA}=(\text { Laba bersih setelah } \\
\text { pajak / total aset }) \times 100 \%\end{array}$ & Rasio & Capital IQ \\
\hline \multicolumn{5}{|c|}{ Variabel Independen } \\
\hline \multirow{3}{*}{$\begin{array}{l}\text { Independensi } \\
\text { Dewan Ko misaris }\end{array}$} & $\begin{array}{c}\text { Proporsi } \\
\text { ko mis aris } \\
\text { independen }\end{array}$ & $\begin{array}{c}\mathrm{KI}=(\text { Ju mlah ko misaris } \\
\text { independen / Jumlah dewan } \\
\text { komisaris }) \times 100 \%\end{array}$ & Rasio & \multirow[b]{2}{*}{$\begin{array}{l}\text { Laporan Tahunan } \\
\text { Perusahaan yang } \\
\text { Diunduh dari } \\
\text { Website BEI }\end{array}$} \\
\hline & $\begin{array}{c}\text { Proporsi } \\
\text { ko misaris } \\
\text { independen yang } \\
\text { me miliki masa } \\
\text { jabatan kurang } \\
\text { dari sembilan } \\
\text { tahun }\end{array}$ & $\begin{array}{l}\text { KIA }=(\text { Ju mlah ko misaris } \\
\text { independen yang memiliki } \\
\text { masa jabatan kurang dari } \\
\text { sembilan tahun / Jumlah } \\
\text { dewan ko misaris }) \text { x } 100 \%\end{array}$ & Rasio & \\
\hline & $\begin{array}{c}\text { Proporsi } \\
\text { ko misaris } \\
\text { independen yang } \\
\text { memiliki jabatan } \\
\text { dewan kurang dari } \\
\text { lima jabatan }\end{array}$ & $\begin{array}{c}\text { KIB = (Ju mlah ko misaris } \\
\text { independen yang memiliki } \\
\text { jabatan dewan kurang dari } \\
\text { lima jabatan / Jumlah dewan } \\
\text { ko misaris ) x } 100 \%\end{array}$ & Rasio & $\begin{array}{l}\text { Laporan Tahunan } \\
\text { Perusahaan yang } \\
\text { Diunduh dari } \\
\text { Website BEI }\end{array}$ \\
\hline $\begin{array}{c}\text { Kompetensi } \\
\text { Dewan Ko misaris }\end{array}$ & $\begin{array}{l}\text { Proporsi dewan } \\
\text { ko misaris yang } \\
\text { me miliki } \\
\text { pengalaman } \\
\text { bekerja di industri } \\
\text { utama perusahaan } \\
\text { beroperasi }\end{array}$ & $\begin{array}{c}\text { KIS = (Ju mlah dewan } \\
\text { ko misaris yang memiliki } \\
\text { pengalaman bekerja di } \\
\text { industri utama perusahaan } \\
\text { beroperasi / Jumlah dewan } \\
\text { komisaris ) x 100\% }\end{array}$ & Rasio & $\begin{array}{l}\text { Laporan Tahunan } \\
\text { Perusahaan yang } \\
\text { Diunduh dari } \\
\text { Website BEI }\end{array}$ \\
\hline $\begin{array}{l}\text { Partisipasi Dewan } \\
\text { Ko misaris }\end{array}$ & $\begin{array}{c}\text { Rata-rata } \\
\text { persentase } \\
\text { kehadiran dewan } \\
\text { komisaris dari } \\
\text { semua rapat } \\
\text { dewan komisaris } \\
\text { dalam satu tahun }\end{array}$ & $\begin{array}{c}\text { KKR = (Ju mlah kehadiran } \\
\text { semua dewan ko misaris / } \\
\text { (Ju mlah rapat dewan } \\
\text { ko misaris dalam satu tahun x } \\
\text { Jumlah dewan ko misaris)) } \mathrm{x} \\
100 \%\end{array}$ & Rasio & $\begin{array}{l}\text { Laporan Tahunan } \\
\text { Perusahaan yang } \\
\text { Diunduh dari } \\
\text { Website BEI }\end{array}$ \\
\hline \multicolumn{5}{|l|}{ Variabel Kontrol } \\
\hline \multirow[t]{3}{*}{ Faktor-faktor Lain } & Leverage & $\begin{array}{c}\text { LEV = (Total debt / Total } \\
\text { ekuitas }) \times 100 \%\end{array}$ & Rasio & \multirow[t]{3}{*}{ Capital IQ } \\
\hline & Firm Size & $\begin{array}{c}\text { FSIZELN = Ln (Harga saham } \\
\text { x Ju mlah saham beredar) }\end{array}$ & Rasio & \\
\hline & Firm Age & $\begin{array}{c}\text { AGELN = Ln }(\text { Umur } \\
\text { Perusahaan })\end{array}$ & Rasio & \\
\hline
\end{tabular}

\section{Model Penelitian}


Model penelitian untuk menguji pengaruh independensi, kompetensi, dan partisipasi dewan komisaris terhadap kinerja keuangan perusahaan menggunakan model regresi berganda sebagai berikut:

$$
\begin{aligned}
& R O A_{i t}=\alpha_{i t}+\beta_{1} K I_{i t}+\beta_{2} K I S_{i t}+\beta_{3} K K R_{i t}+\beta_{4} L E V_{i t}+\beta_{5} \text { SSIZELN }_{i t}+\beta_{6} A G E L N_{i t}+e_{i t} \\
& R O A_{i t}=\alpha_{i t}+\beta_{1} K I A_{i t}+\beta_{2} K I S_{i t}+\beta_{3} K K R_{i t}+\beta_{4} L E V_{i t}+\beta_{5} F S I Z E L N_{i t}+\beta_{6} A G E L N_{i t}+e_{i t} \\
& R O A_{i t}=\alpha_{i t}+\beta_{1} K I B_{i t}+\beta_{2} K I S_{i t}+\beta_{3} K K R_{i t}+\beta_{4} L E V_{i t}+\beta_{5} F S I Z E L N_{i t}+\beta_{6} A G E L N_{i t}+e_{i t}
\end{aligned}
$$

Keterangan:

ROA :Return on Assets

A : Konstanta

$\beta_{\mathrm{i}} \quad$ : Koefisien regresi

KI : Proporsi komisaris independen

KIA :Proporsi komisaris independen yang memiliki masa jabatan kurang dari sembilan tahun

KIB :Proporsi komisaris independen yang memiliki jabatan dewan kurang dari lima jabatan

KIS : Proporsi dewan komisaris yang memiliki pengalaman bekerja di industri utama perusahaan beroperasi

KKR : Rata-rata persentase kehadiran dewan komisaris dari semua rapat dewan komisaris dalam satu tahun

LEV : Leverage perusahaan

FSIZELN: Logaritma natural dari market capitalization perusahaan

AGELN: Logaritma natural dari umur perusahaan

e $\quad$ error

$i \quad$ :entitas ke- $i$

$t \quad$ :periode ke- $t$

\section{Analisis dan Pembahasan}

\section{Statistik Deskriptif}

Hasil dari statistic deskriptif dapat dilihat pada tabel berikut: 
Tabel 4.1 Statistik Deskriptif

\begin{tabular}{|c|c|c|c|c|c|c|}
\hline & Mean & Std. Dev. & Min & Max & Skewness & Kurtosis \\
\hline roa & 0.053 & 0.065 & -0.141 & 0.402 & 1.506 & 7.982 \\
\hline ki & 0.409 & 0.111 & 0.200 & 1.000 & 1.635 & 6.914 \\
\hline kia & 0.355 & 0.152 & 0.000 & 1.000 & -0.130 & 4.608 \\
\hline kib & 0.395 & 0.131 & 0.000 & 1.000 & 0.430 & 6.206 \\
\hline kis & 0.585 & 0.286 & 0.000 & 1.000 & -0.290 & 2.363 \\
\hline kkr & 0.920 & 0.112 & 0.320 & 1.000 & -1.596 & 5.481 \\
\hline lev & 0.740 & 1.525 & -15.872 & 24.325 & 6.462 & 111.276 \\
\hline fsizeln & 26.253 & 4.190 & 15.882 & 33.718 & -0.832 & 2.685 \\
\hline ageln & 3.376 & 0.577 & 1.099 & 5.288 & -0.453 & 4.268 \\
\hline
\end{tabular}

Keterangan:

roa: retum on assets, ki: proporsi komisaris independen, kia: proporsi komisaris independen yang memiliki masa jabat an kurang dari sembilan tahun, kib: proporsi komisaris independen yang memiliki jabatan dewan kurang dari lima jabatan, kis: proporsi dewan komisaris yang memiliki pengalaman bekerja di industri utama perusahaan beroperasi, kkr: rata-rata persentase kehadiran dewan komisaris dari semua rapat dewan komisaris dalam satu tahun, lev: leverage perusahaan, fsizeln: logaritma natural dari market capitalization perusahaan, ageln: logarit ma natural dari umur perusahaan

Sumber: Hasil olah dat a

Hasil statistik deskriptif menunjukkan variabel ROA memiliki rata-rata sebesar 0.053 yang berarti tingkat pengembalian atas aset perusahaan memiliki rata-rata sebesar 5.3 persen dalam sampel penelitian ini. Variabel ROA memiliki rentang nilai dari terendah sebesar -0.141 sampai nilai tertinggi sebesar 0.402. Semakin tinggi nilai ROA menunjukkan semakin efisien kemampuan perusahaan menghasilkan laba dengan menggunakan seluruh asetnya.

Dari 1229 sampel penelitian, nilai variabel proporsi komisaris independen yang terendah adalah 0.200 dan tertinggi adalah satu (seratus persen) dengan rata-rata sebesar 0.409. Hal ini berarti tidak ada perusahaan yang tidak memiliki komisaris independen serta terdapat perusahaan yang semua dewan komisarisnya merupakan komisaris independen. Semakin besar nilai proporsi komisaris independen berarti semakin banyak dewan komisaris dalam suatu perusahaan yang menjabat sebagai komisaris independen.

Nilai rata-rata proporsi komisaris independen yang memiliki masa jabatan kurang dari sembilan tahun sebesar 0.355 dengan nilai minimum sebesar nol dan nilai maksimum sebesar satu (seratus persen). Hal ini menunjukkan bahwa terdapat perusahaan yang sama sekali tidak memiliki komisaris independen yang masa jabatannya kurang dari sembilan tahun dan menurut ASEAN Corporate Governance Scorecard, hal ini dapat membuat tingkat independensi komisaris independen 
tersebut berkurang. Namun, terdapat pula perusahaan yang seluruh komisaris independennya telah menjabat kurang dari sembilan tahun.

Pada variabel proporsi komisaris independen yang memiliki jabatan dewan kurang dari lima jabatan, nilai terkecil adalah nol dan nilai tertinggi adalah satu (seratus persen) dengan nilai rata-rata sebesar 0.395. Angka ini menunjukkan terdapat perusahaan yang sama sekali tidak memiliki komisaris independen yang memiliki jabatan dewan kurang dari lima jabatan. Menurut ASEAN Corporate Governance Scorecard hal ini kurang baik karena akan mengintervensi performa dari komisaris independen tersebut. Akan tetapi, terdapat juga perusahaan yang keseluruhan komisaris independennya memiliki jabatan dewan kurang dari lima jabatan.

Variabel proporsi dewan komisaris yang memiliki pengalaman bekerja di industri utama perusahaan beroperasi memiliki rentang antara nol sampai satu atau seratus persen dengan rata-rata sebesar 0.585 . Hal ini menunjukkan terdapat perusahaan yang seluruh dewan komisarisnya tidak memiliki pengalaman bekerja di industri utama perusahaan tersebut beroperasi. Di sisi lain, terdapat juga perusahaan yang seluruh dewan komisarisnya telah berpengalaman dalam industri utama perusahaan tersebut beroperasi yang dilihat dengan nilai maksimum seratus persen.

Dari seluruh sampel penelitian, variabel rata-rata persentase kehadiran dewan komisaris dari semua rapat dewan komisaris dalam satu tahun memiliki nilai terendah sebesar 0.320 dan nilai tertinggi sebesar satu (seratus persen). Nilai rata-rata variabel ini sebesar 0.920 yang berarti dewan komisaris da lam perusahaan sampel rata-rata menghadiri 92 persen dari semua rapat dewan komisaris dalam satu tahun. Hal ini juga menunjukkan terdapat perusahaan yang seluruh dewan komisarisnya menghadiri semua rapat komisaris dalam setahun. Semakin besar rata-rata persentase kehadiran dewan komisaris dari semua rapat dewan komisaris dalam satu tahun, maka semakin banyak dewan komisaris yang hadir dalam semua rapat dewan komisaris dalam satu tahun.

\section{Hasil Uji Hipotesis}

Pada model 1, 2, dan 3 dalam Tabel 4. 2, nilai Prob>F sebesar 0.0001 menunjukkan bahwa keseluruhan variabel independen da lam penelitian dapat menjelaskan variabel dependen dalam model regresi ini. Nilai R-square within di model 1 menunjukkan nilai 0.1615 yang menggambarkan 


\section{saki}

Studi Akuntansi \& Keuangan Indonesia

variabilitas variabel dependen yang dapat dijelaskan oleh variabel independen adalah sebesar 16.15 persen. Hal ini berarti 16.15 persen kinerja keuangan perusahaan (ROA) dipengaruhi oleh variabel proporsi komisaris independen, proporsi komisaris yang memiliki pengalaman bekerja di industri utama perusahaan beroperasi, dan rata-rata persentase kehadiran dewan komisaris dari semua rapat dewan komisaris dalam satu tahun serta 83.85 persen sisanya dipengaruhi oleh variabel lain di luar penelitian ini. Untuk mode1 2, nilai R-square within menurun sedikit ke angka 0.1614 yang berarti 16.14 persen kinerja keuangan perusahaan (ROA) dipengaruhi oleh variabel independen tersebut dan 83.86 persen sisanya dipengaruhi oleh variabel lain. Selanjutnya pada model 3, nilai R-square within menunjukkan angka yang cukup meningkat yaitu 0.1626 yang artinya 16.26 persen kinerja keuangan perusahaan (ROA) dipengaruhi oleh variabel independen yang ada di penelitian ini dan 83.74 persen sisanya dipengaruhi oleh variabel lainnya.

Tabel 4.2 Hasil Regresi Data Panel

\begin{tabular}{|c|c|c|c|c|c|c|c|c|c|}
\hline & \multicolumn{3}{|c|}{ Model 1} & \multicolumn{3}{|c|}{ Model 2} & \multicolumn{3}{|c|}{ Model 3} \\
\hline roa & Coef. & $\mathrm{P}>|\mathrm{t}|$ & $\mathrm{P}>\mathrm{t} \mid \mathrm{t} / 2$ & Coef. & $\mathrm{P}>|\mathrm{t}|$ & $\mathrm{P}>\mathrm{t} / \mathrm{2}$ & Coef. & $\mathrm{P}>|\mathrm{t}|$ & $\mathrm{P}>\mathrm{t} \mid / 2$ \\
\hline $\mathrm{ki}$ & 0.014 & 0.544 & 0.272 & - & - & - & - & - & - \\
\hline kia & - & - & - & 0.010 & 0.554 & 0.277 & - & - & - \\
\hline kib & - & - & - & - & - & - & 0.021 & 0.348 & 0.174 \\
\hline kis & 0.014 & 0.022 & $0.011 * *$ & 0.014 & 0.018 & $0.009 * * *$ & 0.015 & 0.012 & $0.006 * * *$ \\
\hline $\mathrm{kkr}$ & -0.022 & 0.040 & $0.020 * *$ & -0.022 & 0.037 & $0.018^{* *}$ & -0.023 & 0.038 & $0.019 * *$ \\
\hline lev & -0.001 & 0.051 & $0.025^{* *}$ & -0.001 & 0.046 & $0.023 * *$ & -0.001 & 0.050 & $0.025 * *$ \\
\hline fsize ln & 0.015 & 0.000 & $0.000 * * *$ & 0.015 & 0.000 & $0.000 * * *$ & 0.015 & 0.000 & $0.000 * * *$ \\
\hline ageln & -0.141 & 0.000 & $0.000 * * *$ & -0.141 & 0.000 & $0.000 * * *$ & -0.141 & 0.000 & $0.000 * * *$ \\
\hline Prob $>F$ & \multicolumn{3}{|c|}{0.0001} & \multicolumn{3}{|c|}{0.0001} & \multicolumn{3}{|c|}{0.0001} \\
\hline $\mathrm{F}$ & \multicolumn{3}{|c|}{173.06} & \multicolumn{3}{|c|}{145.93} & \multicolumn{3}{|c|}{140.18} \\
\hline $\begin{array}{c}\text { R-sq } \\
\text { within }\end{array}$ & \multicolumn{3}{|c|}{0.1615} & \multicolumn{3}{|c|}{0.1614} & \multicolumn{3}{|c|}{0.1626} \\
\hline \multicolumn{10}{|c|}{$\begin{array}{l}\text { Keterangan: } \\
\text { *signifikan pada le vel } 10 \% * * \text { signifikan pada le vel } \mathbf{5 \%} \% * * \text { si gnifikan pada le vel } 1 \% \text { (One-tail) } \\
\text { roa: retum on assets, ki: proporsi komisaris independen, kia: proporsi komisaris independen yang memiliki masa jabatan kurang dari sembilan } \\
\text { tahun, kib: proporsi komisaris independen yang memiliki jabatan dewan kurang dari lima jabat an, kis: proporsi dewan komisaris yang memiliki } \\
\text { pengalaman bekerja di industri ut ama perusahaan beroperasi, kkr: rata-rat a persent ase kehadiran dewan komisaris dari semua rapat dewan } \\
\text { komisaris dalam satu tahun, lev: leverage perusahaan, fsizeln: logaritma nat ural dari market capitalization perusahaan, ageln: logaritma nat ural } \\
\text { dari umur perusahaan } \\
\text { Sumber: Hasil olah data }\end{array}$} \\
\hline
\end{tabular}

Berdasarkan Tabel 4.2, dapat dilihat bahwa terdapat tiga variabel independen yang tidak dapat menje laskan variabel dependen secara signifikan yaitu proporsi komisaris independen, proporsi komisaris independen yang memiliki masa jabatan kurang dari sembilan tahun, dan proporsi komisaris independen yang memiliki jabatan dewan kurang dari lima jabatan. Namun, terdapat dua 
variabel independen yang dapat menjelaskan variabel dependen secara signifikan yaitu proporsi komisaris yang memiliki pengalaman bekerja di industri utama perusahaan beroperasi dan rata-rata persentase kehadiran dewan komisaris dari semua rapat dewan komisaris dalam satu tahun. Untuk variabel proporsi komisaris yang memiliki pengalaman bekerja di industri utama perusahaan beroperasi memiliki koefisien pada model 1 sebesar $\mathrm{P}>|\mathrm{t}| / 2=0.011$ yang signifikan pada level lima persen serta pada model 2 sebesar $\mathrm{P}>\mid \mathrm{t} / 2=0.009$ dan model 3 sebesar $\mathrm{P}>\mid \mathrm{t} / 2=0.006$ yang signifikan pada level satu persen. Di sisi lain, variabel rata-rata persentase kehadiran dewan komisaris dari semua rapat dewan komisaris dalam satu tahun memiliki koefisien pada model 1 sebesar $\mathrm{P}>\mid \mathrm{t} / / 2=$ 0.020 , model 2 sebesar $\mathrm{P}>\mid \mathrm{t} / 2=0.018$, dan mode1 3 sebesar $\mathrm{P}>\mid \mathrm{t} / 2=0.019$ yang signifikan pada leve 1 lima persen. Sementara itu, untuk variabel kontrol semua memiliki hasil regresi yang signifikan, untuk leverage signifikan pada level lima persen, sedangkan market capitalization perusahaan dan umur perusahaan signifikan pada level satu persen.

Hubungan antara variabel independen dengan variabel dependen dapat dilihat pada koefisien beta masing-masing variabel dalam Tabe14.12. Untuk koefisien beta proporsi komisaris independen, proporsi komisaris independen yang memiliki masa jabatan kurang dari sembilan tahun, dan proporsi komisaris independen yang memiliki jabatan dewan kurang dari lima jabatan menunjukkan angka positif yang berarti setiap peningkatan proporsi akan meningkatkan kinerja keuangan perusahaan. Koefisien beta variabel proporsi komisaris yang memiliki pengalaman bekerja di industri utama perusahaan beroperasi pada model 1 dan 2 menunjukkan angka positif 0.014 yang berarti setiap kenaikan proporsi komisaris yang memiliki pengalaman bekerja di industri utama perusahaan beroperasi akan meningkatkan ROA sebesar 1.4 persen. Untuk variabel rata-rata persentase kehadiran dewan komisaris dari semua rapat dewan komisaris dalam satu tahun pada model 1 dan 2 menunjukkan koefisien beta negatif 0.022 yang berarti setiap kenaikan rata-rata persentase kehadiran dewan komisaris dari semua rapat dewan komisaris dalam satu tahun akan menurunkan ROA sebesar 2.2 persen.

Tidak jauh berbeda pada model 3, koefisien beta variabel proporsi komisaris yang memiliki pengalaman bekerja di industri utama perusahaan beroperasi menunjukkan angka positif 0.015 yang 
berarti setiap kenaikan proporsi komisaris yang memiliki pengalaman bekerja di industri utama perusahaan beroperasi akan meningkatkan ROA sebesar 1.5 persen. Untuk variabel rata-rata persentase kehadiran dewan komisaris dari semua rapat dewan komisaris dalam satu tahun menunjukkan koefisien beta negatif 0.023 yang berarti setiap kenaikan rata-rata persentase kehadiran dewan komisaris dari semua rapat dewan komisaris dalam satu tahun akan menurunkan ROA sebesar 2.3 persen. Hubungan negatif ini juga terdapat pada variabel leverage dan umur perusahaan, sedangkan market capitalization perusahaan memiliki hubungan yang positif terhadap kinerja keuangan perusahaan.

\section{Pembahasan}

Pengaruh Independensi Dewan Komisaris Terhadap Kinerja Keuangan Perusahaan

Dari hasil regresi pertama, didapatkan bahwa independensi dewan komisaris tidak berpengaruh terhadap kinerja keuangan perusahaan, sehingga hipotesis pertama tidak terbukti. Independensi dewan komisaris diproksikan dengan tiga variabel berbeda antara lain proporsi komisaris independen, proporsi komisaris independen yang memiliki masa jabatan kurang dari sembilan tahun, dan proporsi komisaris independen yang memiliki jumlah jabatan dewan kurang dari lima jabatan. Hasil ini sejalan dengan penelitian di Malaysia (Johl, Kaur, dan Cooper, 2015), Yunani (Drakos dan Bekiris, 2010), Kenya (Ongore, K’Obonyo, Ogutu, dan Bosire; 2015), dan Indonesia (Wulandari, 2006 dan Nathania, 2014) yang menyatakan bahwa banyak komisaris independen yang diangkat bukan karena latar belakang kemampuan yang dimiliki namun karena kepentingan tertentu terhadap perusahaan dan pemilihannya secara subjektif sehingga keberadaan komisaris independen tidak terbukti dapat memengaruhi kinerja keuangan perusahaan.

Jabatan tertentu yang dijabat atau koneksi tertentu yang dimiliki seorang komisaris independen juga dapat memengaruhi pengangkatan komisaris independen ini. Hal ini dapat terjadi karena mungkin saja jabatan tertentu atau koneksi tertentu itu dapat membuat perusahaan melancarkan bisnisnya, misalnya dimudahkan dalam urusan regulasi. Selain itu, keberadaan komisaris independen dalam sebuah perusahaan bisa saja semata-mata dilakukan untuk memenuhi aturan yang 
berlaku sehingga tidak semua komisaris independen yang ada dapat menjalankan tugas sesuai fungsi yang diharapkan.

\section{Pengaruh Kompetensi Dewan Komisaris Terhadap Kinerja Keuangan Perusahaan}

Hasil regresi yang kedua sesuai dengan hipotesis kedua yaitu kompetensi dewan komisaris berpengaruh positif signifikan terhadap kinerja keuangan perusahaan, yang berarti semakin tinggi kompetensi dewan komisaris maka semakin tinggi kinerja keuangan perusahaan. Kompetensi dewan komisaris diproksikan dengan proporsi komisaris yang memiliki pengalaman bekerja di industri utama perusahaan beroperasi dan kinerja keuangan perusahaan diproksikan dengan ROA. Hasil ini juga didukung oleh penelitian yang dilakukan oleh Kor (2003) yang menemukan bahwa semakin tinggi jumlah dewan komisaris yang berkompeten maka semakin tinggi kinerja keuangan perusahaan. Hal ini disebabkan karena dewan komisaris nilai tambah positif untuk kinerja perusahaan karena dianggap telah mengetahui seluk beluk dan dinamika dari industri yang sedang dijalankan. Sela in itu, jika seorang dewan komisaris telah memiliki penga laman industri sebelumnya, maka dewan komisaris dapat memberikan saran, solusi, dan strategi yang lebih terpercaya. Pengetahuan industri yang didapatkan melalui pengalaman industri juga membuat dewan komisaris lebih paham dan ahli dalam memberikan saran dan nasihat untuk perusahaan.

\section{Pengaruh Partisipasi Dewan Komisaris Terhadap Kinerja Keuangan Perusahaan}

Hasil regresi yang ketiga memberi hasil yang berkebalikan dengan hipotesis ketiga, yaitu partisipasi dewan komisaris berpengaruh negatif signifikan terhadap kinerja keuangan perusahaan yang berarti bahwa semakin tinggi partisipasi dewan komisaris maka semakin rendah kinerja keuangan perusahaan. Partisipasi dewan komisaris diproksikan dengan rata-rata persentase kehadiran dewan komisaris dari semua rapat dewan komisaris dalam satu tahun dan kinerja keuangan perusahaan diproksikan dengan ROA. Hal ini dapat terjadi karena kehadiran dewan komisaris dalam rapat hanya untuk formalitas saja dan rapat tidak benar-benar dilaksanakan untuk membahas mengenai perusahaan. Selain itu, hal ini juga dapat terjadi karena memang jumlah rapat yang dilaksanakan memang sedikit sehingga mengharuskan seluruh komisaris untuk datang, sehingga ratarata persentase kehadiran komisaris dapat mencapai seratus persen. Tidak hanya itu saja, jumlah rapat 
yang banyak namun jumlah komisarisnya sedikit mengharuskan semua komisaris menghadiri rapat sehingga membuat rata-rata persentase kehadiran komisaris dapat mencapai seratus persen. Walaupun rata-rata persentase kehadiran dalam rapat ini relatif tinggi untuk 1229 perusahaan-tahun, yaitu hingga mencapai 92 persen, namun ternyata rata-rata persentase kehadiran dalam rapat ini tidak dapat memvalidasi partisipasi dewan komisaris.

\section{Kesimpulan, Implikasi, dan Keterbatasan}

Penelitian ini bertujuan untuk menganalisis pengaruh independensi, kompetensi, dan partisipasi dewan komisaris terhadap kinerja keuangan perusahaan. Hasil pengujian menunjukkan bahwa independensi dewan komisaris tidak berpengaruh terhadap kinerja keuangan perusahaan, kompetensi dewan komisaris berpengaruh positif signifikan terhadap kinerja keuangan perusahaan, dan partisipasi dewan komisaris berpengaruh negatif signifikan terhadap kinerja keuangan perusahaan. Proporsi komisaris independen, proporsi komisaris independen yang memiliki masa jabatan kurang dari sembilan tahun, dan proporsi komisaris independen yang memiliki jumlah jabatan kurang dari lima jabatan tidak berpengaruh terhadap kinerja keuangan perusahaan. Sementara itu, proporsi komisaris yang memiliki pengalaman bekerja di industri utama perusahaan beroperasi berpengaruh positif signifikan terhadap kinerja keuangan perusahaan.

Dalam penerapan tata kelola perusahaan di Indonesia, masih ditemukan beberapa perusahaan yang melanggar peraturan seperti tidak mencantumkan kehadiran dewan komisaris dalam rapat di laporan tahunan perusahaan. Berdasarkan hasil penelitian yang telah dilakukan, pemerintah diharapkan dapat lebih tegas dalam menegakkan hukum yang berlaku bagi perusahaan-perusahaan di Indonesia khususnya untuk menerapkan tata kelola perusahaan yang baik. Dari segi perusahaan juga sebaiknya mempertimbangkan untuk mengangkat dewan komisaris yang memiliki pengalaman yang relevan dengan industri perusahaan sehingga dewan komisaris yang bekerja di dalam perusahaan memiliki kualitas yang terpercaya. Hal ini dikarenakan dengan semakin besarnya proporsi dewan komisaris yang memiliki pengalaman bekerja di industri utama perusahaan akan mendorong kinerja keuangan perusahaan tersebut. Selain itu, perusahaan juga dianjurkan untuk dapat lebih mengefisienkan rapat dewan komisaris yang diadakan dalam satu tahun. Hal ini dimaksudkan agar 
rapat yang diadakan dan dihadiri oleh dewan komisaris merupakan rapat yang dapat menggambarkan partisipasi dewan komisaris dalam perusahaan. Partisipasi dewan komisaris dapat dilihat dari keaktifan dewan komisaris di dalam rapat maupun kualitas pendapat yang diberikan dewan komisaris selama rapat tersebut.

Penelitian ini tidak menemukan adanya pengaruh variabel proporsi komisaris independen, proporsi komisaris independen yang memiliki masa jabatan kurang dari sembilan tahun, dan proporsi komisaris independen yang memiliki jabatan dewan kurang dari lima jabatan terhadap kinerja keuangan perusahaan. Oleh karena itu, penelitian mendatang dapat mencoba kriteria baru dalam meneliti independensi dewan komisaris seperti menambahkan jenis kelamin dewan komisaris maupun umur dewan komisaris dalam suatu perusahaan jika memungkinkan informasi tersebut diakses. Selain itu, dapat pula ditambahkan kriteria latar belakang keahlian dan jabatan yang dijabat sebelumnya khusus komisaris independen. Dari data tersebut dapat dilihat pengaruh independensi dewan komisaris dan dampaknya terhadap kinerja keuangan perusahaan untuk mengkonfirmasi hasil penelitian ini.

\section{Daftar Pustaka}

Agrawal, A., \& Knoeber, C. R. (1996). Firm Performance and Mechanisms to Control Agency Problems between Managers and Shareholders. Journal of Financial and Quantitative Analysis, 31(3), 377-397.

Amyulianthy, R. (2012). Pengaruh Struktur Corporate Governance Terhadap Kinerja Perusahaan Publik Indonesia. Jurnal Liquidity, 1(2), 91-98.

ASEAN Capital Markets Forum. (2015). The ASEAN Corporate Governance Scorecard. Retrieved from http://www.theacmf.org/ACMF/upload/asean_cg_scorecard_20_april_2015

Asian Development Bank. (2014). ASEAN Corporate Governance Scorecard: Country Reports and Assessments 2013-2014. Retrieved from https://www.adb.org/sites/default/files/publication/42600/asean-corporate-governance-scorecard.pdf

Bhatt, R. R., \& Bhattacharya, S. (2015). Board Structure and Firm Performance in Indian IT Firms. Journal of Advances in Management Research, 12(3), 232-248.

Chou, H.I., Chung, H., \& Yin, X. (2013). Attendance of Board Meetings and Company Performance: Evidence from Taiwan. Journal of Banking and Finance, 37, 4157-4171.

Dharmadasa, P., Gamage, P., \& Herath, S. K. (2014). Corporate Governance, Board Characteristics and Firm Performance: Ev idence from Sri Lanka. South Asian Journal of Management, 21(1), 7-32.

Drakos, A. A., \& Bekiris, F. V. (2010). Endogeneity and the Relationship Board Structure and Firm Performance: A Simultaneous Equation Analysis for the Athens Stock Exchange. Managerial and Decision Economics, 31(6), 387-401.

Duchin, R., Matsusaka, J. G., \& Ozbas, O. (2010). When are Outside Directors Effective? Journal of Financial Economics, 96, 195-214.

Erickson, J., Park, Y. W., Reising, J., \& Shin, H. (2005). Board Composition and Firm Value Under Concentrated Ownership: The Canadian Evidence. Pacific-Basin Finance Journal, 13, 387-410. 
Forum for Corporate Governance in Indonesia. (2001). Peranan Dewan Komisaris dan Komite Audit dalam Pelaksanaan Corporate Governance (Tata Kelola Perusahaan). Retrieved from www.fcgi.or.id

Fuzi, S. F. S., Halim, S. A. A., \& Julizaerma, M.K. (2016). Board Independence and Firm Performance. Procedia Economics and Finance, 37(16), 460-465.

Haris, A. (2005). 7 Pilar Perusahaan Unggul. PT Gramedia Pustaka Utama. Retrieved from https://books.google.co.id/books?id=5p4YjfR4ld0C\&pg=PA69\&dq=tata + kelola + perusahaan + adalah $\& h l=e n \& s a=X \& v e d=0$ ahUKEwim4JWG_d3QAhWIM48KHUkSCi8Q6AEIIjAB\#v=onepage\& $q=$ tata kelola perusahaan adalah\& $f=$ false

Hidayat, A. A., \& Utama, S. (2015). Board Characteristics and Firm Performance: Evidence from Indonesia. International Research Journal of Business Studies, 8(3), 137-154.

Hsu, H.E. (2010). The Relationship between Board Characteristics and Financial Performance: An Empirical Study of United States Initial Public Offerings. International Journal of Management, 27(2), 332-342.

Jensen, M. C., \& Meckling, W. H. (1976). Theory of the Firm: Managerial Behavior, Agency Costs, and Ownership Structure. Journal of Financial Economics, 3, 305-360.

Johl, S. K., Kaur, S., \& Cooper, B. J. (2015). Board Characteristics and Firm Performance: Evidence from Malaysian Public Listed Firms. Journal of Economics, Business, and Management, 3(2), 239-243.

Kaihatu, T. S. (2006). Good Corporate Governance dan Penerapannya di Indonesia. Jurnal Ekonomi Manajemen, 1-9.

Kim, S. W. (2011). The Quality Impact of Governance Change on Board Decision Making. Asian Journal on Quality, 12(1), 113-123.

Komite Nasional Kebijakan Governance. (2006). Pedoman Umum Good Corporate Governance Indonesia. Retrieved from www.governance-indonesia.or.id

Kor, Y. Y. (2003). Experience-Based Top Management Team Competence and Sustained Growth. Organization Science, 14(6), 707-719.

Kor, Y. Y., \& Misangyi, V. F. (2008). Outside Directors Industry Specific Experience and Firms Liability of Newness. Strategic Management Joumal, 29(12), 1345-1355.

Kuswadi. (2006). Memahami Rasio Keuangan Orang Awam. PT Elex Media Komputindo. Retrieved from https://books.google.co.id/books?id=VsHn5UGk6CgC\&pg=PA2\&dq=kinerja + perusahaan\& $h l=e n \& s$ $a=X \& v e d=0 a h U K E w j m v v$ Ws193QAhULpo8KHfrtDq44ChDoAQgfMAE\#v=onepage $\& q=k$ inerja perusahaan\& $f=$ false

Lin, Y., Yeh, Y. M. C., \& Yang, F. (2014). Supervisory Quality of Board and Firm Performance: A Perspective of Board Meeting Attendance. Total Quality Management, 25(3), 264-279.

Liu, Y., Miletkov, M. K., Wei, Z., \& Yang, T. (2015). Board Independence and Firm Performance in China. Journal of Corporate Finance, 30, 223-244.

Muntoro, R. K. (2006). Membangun Dewan Komisaris yang Efektif. Retrieved from http://lmfeui.com/data/mui_Membangun Dewan Ko misaris yang Efektif_Ronny K Muntoro.pdf

Nasser, E. M. (2008). Pengaruh Struktur Kepemilikkan Dewan Komisaris Independen terhadap Nilai Perusahaan dengan Manajemen Laba dan Kebijakan Hutang sebagai Variabel Intervening. Media Riset Akuntansi, Auditing, dan Informasi, 8(1), 1-27.

Nathania, A. (2014). Pengaruh Independensi Dewan Perusahaan Terhadap Profitabilitas Perusahaan. FINESTA, 2(1), 76-81.

O’Connell, V., \& Cramer, N. (2010). The Relationship Between Firm Performance and Board Characteristics in Ireland. European Management Joumal, 28(5), 387-399.

Ongore, V. O., K’Obonyo, P. O., Ogutu, M., \& Bosire, E. M. (2015). Board Composition and Financial Performance: Empirical Analysis of Companies Listed at the Nairobi Securities Exchange. International Journal of Economics and Financial Issues, 5(1), 23-39.

Organisation for Economic Co-operation and Development. (2015). OECD Principles of Corporate Governance. World, 46.

Otoritas Jasa Keuangan. (2014). Roadmap Tata Kelola Perusahaan Indonesia: Menuju Tata Kelola Emiten dan Perusahaan Publik yang Lebih Baik.

Undang-undang Nomor 40 Tahun 2007 Tentang Perseroan Terbatas

Widjaja, G. (2008). Seri Pemahaman Perseroan Terbatas: 150 Pertanyaan Tentang Perseroan Terbatas. Jakarta: Forum Sahabat. Retrieved from https://books.google.co.id/books/about/150_pertanyaan_tentang_perseroan_terbata.html $? h l=i d \& i d=V$ U1YFIyBuy0C\&redir_esc $=y$

Widyati, M. F. (2013). Pengaruh Dewan Direksi, Komisaris Independen, Komite Audit, Kepemilikan Manajerial dan Kepemilikan Institusional terhadap Kinerja Keuangan. Jurnal Ilmu Manajemen, 1(1), 234-249. 


\section{saki}

Studi Akuntansi \& Keuangan Indonesia

Wulandari, N. (2006). The Influence of Corporate Governance Mechanism Indicator to Public Company Performance in Indonesia. Fokus Ekonomi, 1(2), 120-136. 